\title{
Synthesis and Antioxidant Evaluation of Enantiomerically Pure Bis-(1,2,3-triazolylmethyl)amino Esters from Modified $\alpha$-Amino Acids
}

\author{
Juan I. Sarmiento-Sánchez, ${ }^{1}$ Adrián Ochoa-Terán, ${ }^{2}$ and Ignacio A. Rivero ${ }^{2}$ \\ ${ }^{1}$ Facultad de Ingeniería, Universidad Autónoma de Sinaloa, Boulevard de las Américas S/N, 80040 Culiacán, SIN, Mexico \\ ${ }^{2}$ Centro de Graduados e Investigación del Instituto Tecnológico de Tijuana, Boulevard Alberto Limón Padilla S/N, \\ Apdo. Postal 1166, 22500 Tijuana, BC, Mexico \\ Correspondence should be addressed to Juan I. Sarmiento-Sánchez; jsarmiento@uas.edu.mx
}

Received 3 June 2014; Accepted 5 August 2014; Published 15 October 2014

Academic Editor: Santiago Garcia-Granda

Copyright (C) 2014 Juan I. Sarmiento-Sánchez et al. This is an open access article distributed under the Creative Commons Attribution License, which permits unrestricted use, distribution, and reproduction in any medium, provided the original work is properly cited.

\begin{abstract}
The efforts for synthesis of enantiomerically pure bis-(1,2,3-triazolylmethyl)amino esters 6 are reported in good yields from an in situ generated $\alpha$-azidomethyl ketone. Optimum experimental conditions were established for preparation of $\alpha$-halomethyl ketones 10 and $\alpha$-N,N-dipropargylamino esters 11, all derived from $\alpha$-amino acids. The starting materials reacted under conventional click chemistry conditions, revealing a specific reactivity of bromomethyl ketones over chloromethyl ketones. The antioxidant activity of compounds 6 was assayed by DPPH method. The compound $6 \mathrm{c}$ with an $\mathrm{IC}_{50}$ of $75.57 \pm 1.74 \mu \mathrm{g} \mathrm{mL} \mathrm{L}^{-1}$ was the most active. Technically, this methodology allows the preparation of a combinatorial library of analogues with different structural characteristics depending on the nature of the modified $\alpha$-amino acids employed in the synthesis.
\end{abstract}

\section{Introduction}

Click chemistry has been defined as an efficient and an almost perfect method (very selective, with high yields and wide scope) for the synthesis of new and diverse compounds based in a carbon-heteroatom bond formation. This reaction has been particularly useful for coupling two molecules, azides and alkynes, to get 1,2,3-triazole compounds [1]. However, it was only after the discovery of copper catalysis that its applications began to be studied [2]. Click chemistry meets the requirements of an innovative functionalization strategy for biomolecules because it is efficient, selective, and without side reactions. Rostovtsev et al. [3] and Tornøe et al. [4] have reported that 1,4-disubstituted 1,2,3-triazoles are specifically prepared from azides and terminal alkynes under copper(I) catalysis to give 1,4-substituted products with high regioselectivity. The regioisomeric 1,5-disubstituted triazoles are available from azides and terminal alkynes by the use of either magnesium acetylides or ruthenium catalysts $[1,5,6]$. 1,2,3-Triazole compounds have attracted attention because they exhibit a broad variety of biological activities. For example, compounds such as $\mathbf{1}$ are active against Mycobacterium tuberculosis [7]; other compounds act as anticancer 2 [8], antifungal 3 [9], or antitumor agents 4 [10], Scheme 1. Some biomedical applications have been described, for example, the labelling of biomolecules [11]. In addition, 1,2,3-triazoles have been used in the coupling of modified $\alpha$-amino acids in oligopeptide synthesis [4, 12-17]. Furthermore, this class of modified oligopeptides $\mathbf{5}$ showed activity as inhibitors of cysteine protease CPB2.8 $\triangle \mathrm{CTE}$ in Leishmania mexicana [18] and antiviral activity against HIV-1 gp120 [19, 20].

The cycloaddition of azides and alkynes is typically carried out in refluxing toluene, but labile molecules may not be stable under these conditions. Also, although organic azides are generally safe compounds, those of low molecular weight can be unstable and, therefore, difficult to handle. This is especially true for small molecules with several azide functionalities, which would be of much interest for the generation of polymeric structures. Thus, a methodology that avoids isolation of organic azides as intermediates is 
<smiles>[R][X]c1ccc2c(c1)CC(Cn1cc([R])nn1)O2</smiles>

$$
\begin{aligned}
& \mathrm{R}=-4-\mathrm{CHO} \\
& -4-\mathrm{CHO} \\
& -4-\mathrm{CHO} \\
& -4-\mathrm{CHO} \\
& \begin{array}{c}
\mathrm{R}^{1}=-\left(\mathrm{CH}_{2}\right)_{4} \mathrm{CH}_{3} \\
-\mathrm{CH}_{2} \mathrm{OH} \\
-\mathrm{C}_{6} \mathrm{H}_{5} \\
-\mathrm{CH}_{2} \mathrm{C}_{6} \mathrm{H}_{5}
\end{array}
\end{aligned}
$$$$
\mathrm{R}^{1}=\mathrm{H}, \mathrm{R}^{2}=\mathrm{CH}_{3}, \mathrm{R}^{3}=\mathrm{H}
$$$$
\mathrm{R}^{1}=\mathrm{H}, \mathrm{R}^{2}=\mathrm{H}, \mathrm{R}^{3}=\mathrm{NO}_{2}
$$<smiles>[R]c1ccc(Cn2cc(CNS(=O)(=O)c3ccc(N)cc3)nn2)c([R])c1[R]</smiles>

3<smiles>COc1ccc(C(=O)c2nnn3c2OCC3)cc1</smiles>

2

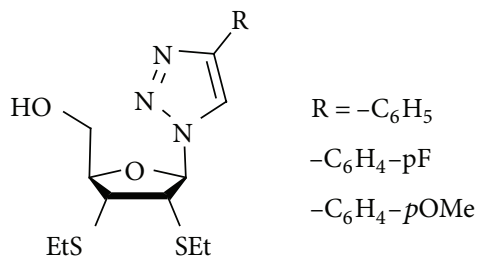
4

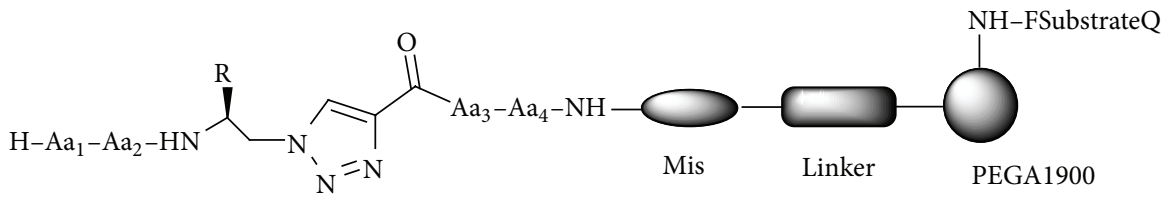

desirable. In literature have been reported some procedures to synthesize 1,2,3-triazoles where the organic azide is generated in situ [21-24].

Moreover, enantiomerically pure $\alpha$-halomethyl ketones can be prepared from $\alpha$-amino acids modifying the carboxylic group into a halomethyl group. Its selective reduction with sodium borohydride affords the erythro-amino alcohols as main products. As a result, these $\alpha$-halomethyl ketones are often used as key intermediates in the stereoselective synthesis of biological active compounds [25]. In this sense, the $\mathrm{N}$-acylated $\alpha$-chloromethyl ketones are used as enzyme inhibitors [26, 27] and serve as precursors for the synthesis of the hydroxyethylamine isosteres, which are present in many of the inhibitors of angiotensin converting enzyme [28], renin [29], and HIV protease [30]. The $\alpha$-chloromethyl ketones are typically converted to chlorohydrins and epoxides, which react with nucleophiles in the preparation of various enzyme inhibitors [25]. A typical reaction to prepare $\alpha$-halomethyl ketones involves the conversion of $\mathrm{N}$-acylated $\alpha$-amino acid into $\alpha$-diazoketone and a subsequent treatment with HX [31]. This procedure requires large amounts of diazomethane to produce $\alpha$-halomethyl ketones; for this reason it is considered as an unsafe procedure. In recent years, the use of $\alpha$ halomethyl ketones as intermediates in the synthesis of enantiomerically pure heterocyclic compounds, such as epoxides, azetidines, and aziridines, has been reported [32-35]. Furthermore, enantiomerically pure $\alpha$-bromomethyl ketones can be prepared from $\alpha$-amino esters and bromomethyllithium generated in situ $[36,37]$. This procedure prevents the use of diazomethane and minimizes racemization.

On the other hand, there is an increasing interest in compounds with high antioxidants activities, which could counteract the oxidative stress associated with diseases. Antioxidant activity screening is commonly done by in vitro assays, such as the $\mathrm{ABTS}^{\bullet+}[38]$, ferric-reducing $[39,40]$, and DPPH $[41,42]$ methods.

Recently, we have reported the synthesis of new enantiomerically pure compounds from chemical modifications of $\alpha$-amino acids [43-45]. Continuing our research interest in triazoles chemistry $[46,47]$, now we report our efforts in the synthesis of new enantiopure 1,4-disubstituted 1,2,3triazoles via conventional Huisgen cycloaddition using $\alpha$ halomethyl ketones 10 and $\alpha$-N,N-dipropargylamino esters 11 as one strategy for coupling in solution two enantiopure moieties derived from $\alpha$-amino acids. From a combinatorial chemistry approach, the methodology developed in the present work could allow preparing a library of analogues, depending on the number and nature of $\alpha$ amino acids synthetically modified. It is then feasible to expect a different behavior for each one of the possible 


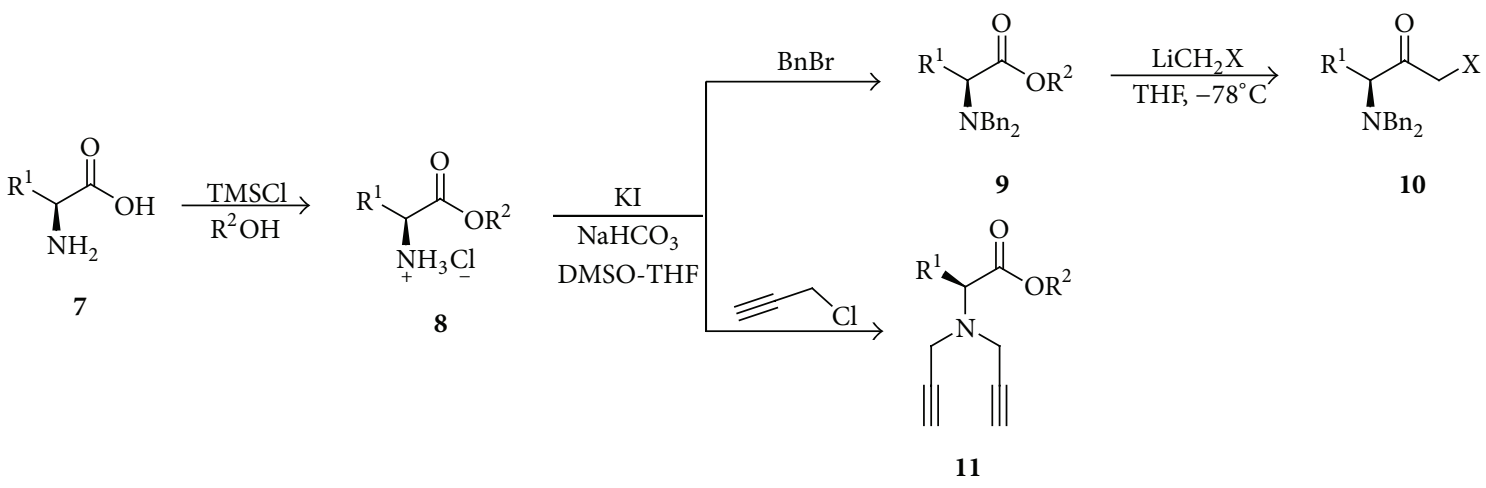

SCHeme 2: Synthesis of starting compounds from $\alpha$-amino acids.

TABLE 1: $\alpha$-Halomethyl ketones synthesized from $\alpha$-amino acids.

\begin{tabular}{lccc}
\hline Compound & $\mathrm{R}^{1}$ & $\mathrm{X}$ & Yield (\%) \\
\hline 10a & $-\mathrm{CH}_{3}$ & $\mathrm{Cl}$ & 86 \\
10b & $-\mathrm{H}$ & $\mathrm{Cl}$ & 80 \\
10c & $-\mathrm{CH}_{2} \mathrm{Ph}$ & $\mathrm{Cl}$ & 90 \\
10d & $\mathrm{TBDMSOCH}_{2}-$ & $\mathrm{Cl}$ & 65 \\
10e & $-\mathrm{CH}_{3}$ & $\mathrm{Br}$ & 90 \\
10f & $-\mathrm{H}$ & $\mathrm{Br}$ & 83 \\
\hline
\end{tabular}

products. We envisioned potential for these new bis-(1,2,3triazolylmethyl)amino esters 6 (Scheme 3) as biologically active substances and as building blocks for the syntheses of interesting modified oligopeptides.

\section{Results and Discussion}

2.1. Synthesis of Modified $\alpha$-Amino Acids as Starting Materials for Click Chemistry. The synthesis of enantiopure $\alpha$ halomethyl ketones $\mathbf{1 0}$ and $\alpha$-N,N-dipropargylamino esters 11 can be achieved following the methodology depicted in Scheme 2. $\alpha$-Amino acids 7 were esterified with excellent yields using trimethylsilyl chloride (TMSCl) and methanol or ethanol as solvent. Then, compounds $\mathbf{8}$ are alkylated under basic conditions using benzyl bromide to obtain $N, N$ dibenzylamino esters 9, which react with methyllithium chloride or methyllithium bromide in situ generated in order to obtain the enantiopure compounds 10. The $\alpha$-halomethyl ketones synthesized only were characterized for NMR and immediately used for the next step in the reaction. Yields for the $\alpha$-halomethyl ketones synthesized with this procedure are shown in Table 1.

For the synthesis of enantiopure dialkynes several $\alpha$ amino acids were modified. The subsequent reaction of $\alpha$ amino esters $\mathbf{8}$ with propargyl chloride was carried out in order to obtain $N, N$-dipropargylamino esters 11 with isolated yields between 59 and $87 \%$ (Table 2). The propargylamino esters $\mathbf{1 1}$ and halomethyl ketones $\mathbf{1 0}$ compounds were characterized for NMR and immediately were used for the synthesis of bis-(1,2,3-triazolylmethyl)amino esters.
TABLE 2: Dialkynes synthesized from $\alpha$-amino acids.

\begin{tabular}{lccc}
\hline Compound & $\mathrm{R}^{1}$ & $\mathrm{R}^{2}$ & Yield (\%) \\
\hline 11a & $-\mathrm{CH}_{3}$ & $-\mathrm{CH}_{3}$ & 85 \\
11b & $-\mathrm{H}$ & $-\mathrm{CH}_{2}-\mathrm{CH}_{3}$ & 67 \\
11c & $-\mathrm{CH}_{2}$ Indol & $-\mathrm{CH}_{3}$ & 87 \\
11d & $-\mathrm{CH}_{2} \mathrm{Ph}$ & $-\mathrm{CH}_{3}$ & 74 \\
11e & $-\mathrm{CH}_{2} \mathrm{OH}$ & $-\mathrm{CH}_{2}-\mathrm{CH}_{3}$ & 59 \\
\hline
\end{tabular}

2.2. Synthesis of Bis-(1,2,3-triazolylmethyl)amino Esters and Antioxidant Evaluation. As is depicted in Scheme 3, the key process in the synthesis of bis-(1,2,3-triazole) compounds 6 is the in situ generation of $\alpha$-azidomethyl ketones $[48,49]$ by the reaction of sodium azide with $\alpha$-halomethyl ketones 10. First, the synthesis of bis-(1,2,3-triazole) $\mathbf{6} \mathbf{a}$ was studied as model reaction in order to establish the optimum time required to complete the reaction. The bromomethyl ketone $10 \mathrm{e}$ and dialkyne 11a were used as starting materials in aqueous tert-butyl alcohol $\left({ }^{t} \mathrm{BuOH} / \mathrm{H}_{2} \mathrm{O} 1: 1 \mathrm{v} / \mathrm{v}\right)$. The reaction was monitored during seven days by TLC. After this time starting materials were still present in the mixture. After reaction workup the product was isolated with $25 \%$ yield. Thus, based on our experience in the synthesis of 1,2,3-triazoles [46, 47], the temperature reaction was increased to $60^{\circ} \mathrm{C}$ and the product was identified by TLC after $12 \mathrm{~h}$ and at $48 \mathrm{~h}$ the product 6 a was isolated with $65 \%$ yield.

Subsequently, four bis-(1,2,3-triazolylmethyl)amino esters 6 were synthesized by thermally inducing the Huisgen cycloaddition reaction between ketone $\mathbf{1 0 e}$ and dialkynes $\mathbf{1 1}$. A temperature of $60^{\circ} \mathrm{C}$ and a time of $48 \mathrm{~h}$ were the optimal conditions for the synthesis of the products. The isolated product yields were in the range from 55 to $76 \%$, depending on the dialkyne used as starting material (Table 3). The higher yield obtained for product $\mathbf{6} \mathbf{b}$ could be explained considering the role of the indole ring when the substrate interacts with copper(I) ion stabilizing the complex for longer time and favoring the formation to diacetylides in click reaction (Scheme 3 ). When bromomethyl ketone $\mathbf{1 0 f}$ was used for the reaction, the products were detected by TLC and ESI-MS, but it was not possible to isolate them by chromatography using alumina or silica gel. 


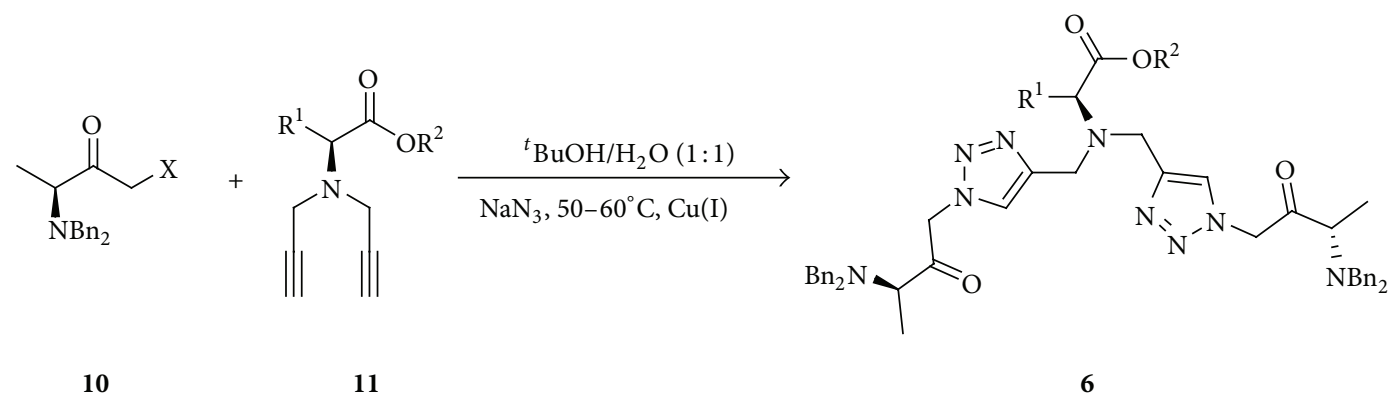

Scheme 3: Synthesis of bis-(1,2,3-triazolyl) compounds using modified $\alpha$-amino acids.

TABLE 3: Yield and antioxidant activity of bis-(1,2,3-triazolylmethyl)amino esters 6.

\begin{tabular}{lcccc}
\hline Product & $\mathrm{R}^{1}$ & $\mathrm{R}^{2}$ & Yield \% & $\begin{array}{c}\text { Antioxidant } \\
\text { activity } \\
\mathrm{IC}_{50}\left(\mu \mathrm{gL}^{-1}\right)^{\mathrm{a}}\end{array}$ \\
\hline 6a & $-\mathrm{CH}_{3}$ & $-\mathrm{CH}_{3}$ & 65 & $317.68 \pm 74.16$ \\
6b & $-\mathrm{CH}_{2} \mathrm{Indol}$ & $-\mathrm{CH}_{3}$ & 76 & $774.26 \pm 112.64$ \\
$\mathbf{6 c}$ & $-\mathrm{H}$ & $-\mathrm{CH}_{2} \mathrm{CH}_{3}$ & 50 & $75.57 \pm 1.74$ \\
6d & $-\mathrm{CH}_{2} \mathrm{OH}$ & $-\mathrm{CH}_{2} \mathrm{CH}_{3}$ & 55 & - \\
Vitamin C & & & - & $8.48 \pm 1.07$ \\
Gallic acid & & & - & $6.33 \pm 0.66$ \\
\hline
\end{tabular}

${ }^{\mathrm{a}}$ Values represent mean \pm standard deviation, $n=3$.

Chloromethyl ketones $\mathbf{1 0 a}-\mathbf{d}$ were also studied, but the expected products were not detected by TLC or isolated after workup. We assumed that, as chloromethyl ketones are less reactive than bromomethyl ketones, the formation of azides was not achieved and in consequence neither was the cycloaddition process.

It is noteworthy that in the ${ }^{1} \mathrm{H}-\mathrm{NMR}$ spectra of compounds 6a-d some signals appeared as overlapping peaks due to the similarity of the chemical environment of the hydrogens in the molecule, however, is possible to distinguish two signals between 5 and 6 ppm corresponding to the hydrogens of methylene attached to the triazole and the ketone carbonyl groups. The signal for triazole hydrogen appears at 7.22 ppm overlapping with other aromatic hydrogens. In the ${ }^{13} \mathrm{C}$ NMR spectra the significant signals appear at $203 \mathrm{ppm}$ for the ketone carbonyl, at $174 \mathrm{ppm}$ for ester carbonyl, and at $146 \mathrm{ppm}$ and $124 \mathrm{ppm}$ for the two carbons of triazole ring. In the ESI-MS analysis the quasimolecular ions for all products were detected. These spectroscopic data are clear evidence supporting the formation of the assigned products.

In the antioxidant activity, gallic acid, ascorbic acid, and BHT are commonly used as reference standards in a comparative evaluation of antioxidant properties of new molecules [50]. Thus, the bis-(1,2,3-triazoles)amino esters 6 were assayed up to $100 \mu \mathrm{g} \mathrm{mL}^{-1}$ and presented less activity than reference standards (Table 3 ). The compound $\mathbf{6 c}$ showed the higher activity at $75.57 \pm 1.74 \mu \mathrm{g} \mathrm{mL}^{-1}$ being 4.2 -fold and 10.2 -fold more active than $\mathbf{6} \mathbf{a}$ and $\mathbf{6} \mathbf{b}$, respectively.

\section{Conclusions}

In this work we have developed a methodology for the synthesis of enantiomerically pure bis-(1,2,3-triazolylmethyl)amino esters in good yields. Also, the in situ formation of organic azides from $N, N$-dibenzylamino $\alpha$-halomethyl ketones as a key intermediate was implemented. An easy methodology was used to synthesize new dialkynes derived from $\alpha$-amino acids. The results gave significant information about the specificity of the reactivity of halomethyl ketones for the synthesis of these new materials, those containing bromine being the most suitable. The developed methodology allows preparation of a combinatorial library of analogues with different structural characteristics depending on the nature of the modified $\alpha$-amino acids employed in the synthesis.

\section{Experimental Section}

4.1. General Procedures. All reagents were purchased in the highest quality available and were used without further purification. The solvents used in column chromatography were obtained from commercial suppliers and used without distillation. Infrared spectra (FTIR) were recorded on a Perkin Elmer FT-IR 1600 spectrophotometer. Nuclear magnetic resonance ${ }^{1} \mathrm{H}$ (at $200 \mathrm{MHz}$ ) and ${ }^{13} \mathrm{C}$ (at $50 \mathrm{MHz}$ ) spectra were recorded on a Varian Mercury $200 \mathrm{MHz}$ Spectrometer in $\mathrm{CDCl}_{3}$ with TMS as internal standard. ESI-MS spectra were obtained with an ion trap, and the intensities are reported as a percentage relative to the base peak after the corresponding $m / z$ value. HRMS was recorded on an ESI/APCI-TOF Bruker model MicroTOF-II-Focus at the Universidad Autónoma Metropolitana, Campus Iztapalapa. Melting points were obtained on an Electrothermal 88629 apparatus.

4.2. General Procedure for the Synthesis of Bis-(1,4-disubstituted-1,2,3-triazoles). To a solution of $\alpha$-halomethyl ketone (2 equiv.) in tert-BuOH/ $\mathrm{H}_{2} \mathrm{O}(4 \mathrm{~mL} 1: 1 \mathrm{v} / \mathrm{v})$ were added sodium azide (2 equiv.), dialkyne ( $200 \mathrm{mg}$, 1 equiv.), copper(II) sulfate pentahydrate $(5 \% \mathrm{~mol})$, and sodium ascorbate $(10 \% \mathrm{~mol})$, with vigorous stirring at $60^{\circ} \mathrm{C}$ for $48 \mathrm{~h}$. The reaction mixture was then filtered through diatomaceous earth and silica gel under reduced pressure and then extracted with ethyl acetate $(4 \times 20 \mathrm{~mL})$. The extracts were combined and dried over anhydrous sodium sulfate. After evaporation 
of the solvent, the resulting oil was purified by flash chromatography.

Methyl (S)-2-[bis-[[1-[(S)-3-(dibenzylamino)-2-oxobutyl]-1H-1,2,3-triazol-4-yl]methyl]-amino]propanoate (6a). Yield 65\%; pale yellow solid; $[\alpha]^{20}{ }_{D}=-14.3(c=1.33$ in $\mathrm{MeOH}) ;{ }^{1} \mathrm{H} \mathrm{NMR}\left(\mathrm{CDCl}_{3}, 200 \mathrm{MHz}\right): \delta 7.47-7.04(\mathrm{~m}$, $22 \mathrm{H}), 5.66(\mathrm{~d}, 2 \mathrm{H}, J=18.4 \mathrm{~Hz}), 5.09(\mathrm{~d}, 2 \mathrm{H}, J=18.4 \mathrm{~Hz})$, 3.99-3.39 (m, 18H), 1.43-1.06 (m, 9H); ${ }^{13} \mathrm{C} \mathrm{NMR}\left(\mathrm{CDCl}_{3}\right.$, $75 \mathrm{MHz}$ ): $\delta$ 202.9, 174.3, 146.0, 138.2, 128.9, 128.8, 127.7, 124.6, $61.4,56.4,55.6,54.9,51.5,45.6,15.5,6.0$. IR (KBr, pellet): $3144,1734,1654,1602,1454,1148 \mathrm{~cm}^{-1}$. ESI-MS $\mathrm{m} / z: 796$ $[\mathrm{M}+\mathrm{H}]^{+}, 818[\mathrm{M}+\mathrm{Na}]^{+}$. HRMS calculated for $\mathrm{C}_{46} \mathrm{H}_{54} \mathrm{~N}_{9} \mathrm{O}_{4}$ $\left(\mathrm{MH}^{+}\right)$796.4293; found: 796.4294.

Methyl (S)-2-[bis[[1-[(S)-3-(dibenzylamino)-2-oxobutyl]-1H-1,2,3-triazol-4-yl]methyl]-amino]-3-(1H-indol-3-yl) propanoate (6b). Yield 76\%; grey solid; m.p. $205-207^{\circ} \mathrm{C}$; $[\alpha]^{20}{ }_{D}=-37.0\left(c=0.88\right.$ in $\left.\mathrm{CH}_{2} \mathrm{Cl}_{2}\right) ;{ }^{1} \mathrm{H}$ NMR $\left(\mathrm{CDCl}_{3}\right.$, $200 \mathrm{MHz}): \delta 8.24-6.52(\mathrm{~m}, 27 \mathrm{H}), 5.74-5.58(\mathrm{dd}, 2 \mathrm{H}, J=16.2$, $14.7 \mathrm{~Hz}), 5.48-5.33(\mathrm{dd}, 2 \mathrm{H}, J=12.0,11.9 \mathrm{~Hz}), 5.09-4.92$ $(\mathrm{dd}, 2 \mathrm{H}, J=14.5,18.5 \mathrm{~Hz}), 3.99-3.20(\mathrm{~m}, 20 \mathrm{H}), 1.20(\mathrm{~s}$, $6 \mathrm{H}) ;{ }^{13} \mathrm{C} \mathrm{NMR}\left(\mathrm{CDCl}_{3}, 75 \mathrm{MHz}\right): \delta 203.3,203.2,173.3,146.7$, 146.6, 138.2, 135.6, 128.8, 128.5, 128.4, 127.7, 127.3, 127.2, 124.3, $124.2,121.3,118.9,118.7,111.2,110.7,65.8,62.6,61.7,61.5,56.1$, 54.8, 51.4, 46.4, 46.1, 25.7, 6.0, 5.8; FTIR (KBr, pellet): 3414, $1732,1620,1602,1494,1454 \mathrm{~cm}^{-1}$; ESI-MS $m / z: 911[\mathrm{M}+\mathrm{H}]^{+}$, $933[\mathrm{M}+\mathrm{Na}]^{+}$. HRMS calculated for $\mathrm{C}_{54} \mathrm{H}_{59} \mathrm{~N}_{10} \mathrm{O}_{4}\left(\mathrm{MH}^{+}\right)$ 911.4715; found: 911.4705 .

Ethyl $\quad N$-((1- $((R)-3-($ dibenzylamino)-2-oxobutyl)- $1 H$ 1,2,3-triazol-4-yl)methyl)-N-((1-(3-(dibenzylamino)-2-oxobutyl)-1H-1,2,3-triazol-4-yl)methyl)glycinate (6c). Yield $50 \%$; $[\alpha]^{20}{ }_{D}=-5.6\left(c=0.14\right.$ in $\left.\mathrm{CH}_{2} \mathrm{Cl}_{2}\right) ;{ }^{1} \mathrm{H}$ NMR $\left(\mathrm{CDCl}_{3}\right.$, $200 \mathrm{MHz}): \delta 7.81-7.23(\mathrm{~m}, 22 \mathrm{H}), 5.72(\mathrm{~d}, 2 \mathrm{H}, J=18.8 \mathrm{~Hz})$, $5.15(\mathrm{~d}, 2 \mathrm{H}, J=18.8 \mathrm{~Hz}), 3.81-3.34(\mathrm{~m}, 18 \mathrm{H}), 1.23(\mathrm{~s}, 9 \mathrm{H})$; ${ }^{13} \mathrm{C} \mathrm{NMR}\left(\mathrm{CDCl}_{3}, 75 \mathrm{MHz}\right): \delta 203.7,171.3,144.0,138.3,128.9$, $128.8,127.7,125.3,63.2,61.5,60.8,56.5,54.9,47.9,14.2,6.1$; ESI-MS m/z: $796[\mathrm{M}+\mathrm{H}]^{+}, 818[\mathrm{M}+\mathrm{Na}]^{+}$.

Ethyl $\quad N$-((1- $((R)-3-($ dibenzylamino)-2-oxobutyl)-1H1,2,3-triazol-4-yl)methyl)- $N$-((1-((S)-3-(dibenzylamino)-2oxobutyl)-1H-1,2,3-triazol-4-yl)methyl)- $D$-serinate (6d). Yield 55\%; pale yellow solid; ${ }^{1} \mathrm{H} \mathrm{NMR}\left(\mathrm{CDCl}_{3}, 200 \mathrm{MHz}\right)$ : $\delta 7.38-7.27(\mathrm{~m}, 22 \mathrm{H}), 5.65(\mathrm{~d}, 2 \mathrm{H}, J=17.6 \mathrm{~Hz}), 5.08(\mathrm{~d}, 2 \mathrm{H}$, $J=18.3 \mathrm{~Hz}), 4.18-3.51(\mathrm{~m}, 20 \mathrm{H}), 1.27(\mathrm{~s}, 9 \mathrm{H}) ;{ }^{13} \mathrm{C} \mathrm{NMR}$ $\left(\mathrm{CDCl}_{3}, 75 \mathrm{MHz}\right): \delta 203.1,171.3,146.1,138.3,128.9,128.8$, 127.7, 124.3, 64.9, 61.5, 60.8, 59.8, 56.4, 54.9, 46.4, 14.3, 6.0; ESI-MS $m / z: 827[\mathrm{M}+\mathrm{H}]^{+}$.

4.3. DPPH-Scavenging Activity. The DPPH-scavenging activities of the bis-(1,2,3-triazoles)amino esters 6 were assessed as described by Sivakumar et al. [51] with slight modifications. This method is based on the reduction of DPPH in the presence of antioxidants; the antioxidant activity is detected as a change from purple to yellow color in the solution. Briefly, a solution of DPPH $(0.10 \mathrm{mM})$ in methanol (grade HPLC) was prepared. Then, $50 \mu \mathrm{L}$ of the bis-(1,2,3triazoles)amino esters $\left(0.1-25 \mu \mathrm{g} \mathrm{mL}^{-1}\right.$ in methanol) was mixed with $1.950 \mathrm{~mL}$ of the DPPH solution and the mixture is incubated for $20 \mathrm{~min}$ at room temperature in darkness conditions, and the absorbance was measured at $517 \mathrm{~nm}$
(Spectronic Genesys 5). The DPPH-scavenging activity of the bis-(1,2,3-triazoles)amino esters 6 was calculated as follows:

$$
\text { DPPH-scavenging effect }(\%)=\left[\frac{\left(A_{0}-A_{1}\right)}{A_{0}}\right] \times 100 \text {, }
$$

where $A_{0}$ was the absorbance of control and $A_{1}$ was the absorbance in the presence of the bis-(1,2,3-triazoles)amino esters. The same methodology was used for assaying the references standard vitamin $C$ and gallic acid $\left(0.1-25 \mu \mathrm{g} \mathrm{mL}^{-1}\right.$ in methanol). The bis-(1,2,3-triazoles)amino esters and reference standard are expressed as inhibitory concentration mean $\left(\mathrm{IC}_{50}\right)$. Linear regression analysis was used to calculate the $\mathrm{IC}_{50}$ values and corresponded to the mean \pm standard deviation of one experiment by triplicate and was determined by SPSS Statistics software v19 (IBM company).

\section{Conflict of Interests}

The authors declare that there is no conflict of interests regarding the publication of this paper.

\section{Authors' Contribution}

Juan I. Sarmiento-Sánchez and Ignacio A. Rivero equally contributed to the paper.

\section{Acknowledgments}

The authors gratefully acknowledge the support for this project by Consejo Nacional de Ciencia y Tecnología (SEPCONACyT: Grant no. CB-2012-178266-Q and CONACyT: Grant no. SEP-2004-CO1-47835). They also thank Dr. Miguel P. Parra Hake for his help and suggestions in writing this paper.

\section{References}

[1] A. Krasiński, V. V. Fokin, and K. B. Sharpless, "Direct synthesis of 1,5-disubstituted-4-magnesio-1,2,3-triazoles, revisited," Organic Letters, vol. 6, no. 8, pp. 1237-1240, 2004.

[2] H. C. Kolb, M. G. Finn, and K. B. Sharpless, "Click chemistry: diverse chemical function from a few good reactions," Angewandte Chemie, vol. 40, no. 11, pp. 2004-2021, 2001.

[3] V. V. Rostovtsev, L. G. Green, V. V. Fokin et al., "A stepwise huisgen cycloaddition process: copper(I)-catalyzed regioselective "ligation" of azides and terminal alkynes," Angewandte Chemie International Edition, vol. 41, no. 14, pp. 2596-2599, 2002.

[4] C. W. Tornøe, C. Christensen, and M. Meldal, "Peptidotriazoles on solid phase: [1,2,3]-Triazoles by regiospecific copper(I)catalyzed 1,3-dipolar cycloadditions of terminal alkynes to azides," The Journal of Organic Chemistry, vol. 67, no. 9, pp. 3057-3064, 2002.

[5] L. Zhang, X. Chen, P. Xue et al., "Ruthenium-catalyzed cycloaddition of alkynes and organic azides," Journal of the American Chemical Society, vol. 127, no. 46, pp. 15998-15999, 2005.

[6] L. K. Rasmussen, B. C. Boren, and V. V. Fokin, "Rutheniumcatalyzed cycloaddition of aryl azides and alkynes," Organic Letters, vol. 9, no. 26, pp. 5337-5339, 2007. 
[7] R. P. Tripathi, A. K. Yadav, A. Ajay, S. S. Bisht, V. Chaturvedi, and S. K. Sinha, "Application of Huisgen $(3+2)$ cycloaddition reaction: synthesis of 1-(2,3-dihydrobenzofuran-2-yl-methyl [1,2,3]-triazoles and their antitubercular evaluations," European Journal of Medicinal Chemistry, vol. 45, no. 1, pp. 142-148, 2010.

[8] S.-J. Yan, Y.-J. Liu, Y.-L. Chen, L. Liu, and J. Lin, "An efficient one-pot synthesis of heterocycle-fused 1,2,3-triazole derivatives as anti-cancer agents," Bioorganic \& Medicinal Chemistry Letters, vol. 20, no. 17, pp. 5225-5228, 2010.

[9] X. Wang, G. Ling, Y. Xue, and S. Lu, "Selenium-catalyzed reductive carbonylation of 2-nitrophenols to 2-benzoxazolones," European Journal of Organic Chemistry, vol. 2005, no. 8, pp. 1675-1679, 2005.

[10] J.-L. Yu, Q.-P. Wu, Q.-S. Zhang, Y. Liu, Y. Li, and Z. Zhou, "Synthesis and antitumor activity of novel $2^{\prime}, 3^{\prime}$-dideoxy-2', $3^{\prime}$ diethanethionucleosides bearing 1,2,3-triazole residues," Bioorganic and Medicinal Chemistry Letters, vol. 20, no. 1, pp. 240243, 2010.

[11] G. Ferro-Flores, I. A. Rivero, C. L. Santos-Cuevas et al., "Click chemistry for [99mTc(CO)3] labeling of Lys3-bombesin," Applied Radiation and Isotopes, vol. 68, no. 12, pp. 2274-2278, 2010.

[12] T. Aravinda, H. S. Bhojya Naik, and H. R. Prakash Naik, "1,2,3triazole fused quinoline-peptidomimetics: studies on synthesis, DNA binding and photonuclease activity," International Journal of Peptide Research and Therapeutics, vol. 15, no. 4, pp. 273-279, 2009.

[13] A. Tam, U. Arnold, M. B. Soellner, and R. T. Raines, "Protein prosthesis: 1,5-Disubstituted[1,2,3] triazoles as cis-peptide bond surrogates," Journal of the American Chemical Society, vol. 129, no. 42, pp. 12670-12671, 2007.

[14] N. Narendra, T. M. Vishwanatha, and V. V. Sureshbabu, "Peptidomimetics through click chemistry: synthesis of novel $\beta$ Keto triazole acids from $N$-protected amino acids," International Journal of Peptide Research and Therapeutics, vol. 16, no. 4, pp. 283-290, 2010.

[15] H. P. Hemantha, R. S. Lamani, and V. V. Sureshbabu, "Synthesis of Hybrid Peptidomimetics and Neoglycoconjugates Employing Click Protocol: dual utility of Poc-group for inserting carbamate-triazole units into peptide backbone," International Journal of Peptide Research and Therapeutics, vol. 16, no. 4, pp. 267-275, 2010.

[16] Z. Zhang and E. Fan, "Solid phase synthesis of peptidotriazoles with multiple cycles of triazole formation," Tetrahedron Letters, vol. 47, no. 5, pp. 665-669, 2006.

[17] Y. Liu, L. Zhang, J. Wan, Y. Li, Y. Xu, and Y. Pan, "Design and synthesis of cyclo[-Arg-Gly-Asp- $\Psi$ (triazole)-Gly-Xaa-] peptide analogues by click chemistry," Tetrahedron, vol. 64, no. 47, pp. 10728-10734, 2008.

[18] C. W. Tornøe, S. J. Sanderson, J. C. Mottram, G. H. Coombs, and M. Meldal, "Combinatorial library of peptidotriazoles: identification of [1,2,3]-triazole inhibitors against a recombinant Leishmania mexicana cysteine protease," Journal of Combinatorial Chemistry, vol. 6, no. 3, pp. 312-324, 2004.

[19] M. Umashankara, K. McFadden, I. Zentner et al., "The active core in a triazole peptide dual-site antagonist of HIV-1 gp120," ChemMedChem, vol. 5, no. 11, pp. 1871-1879, 2010.

[20] H. Gopi, S. Cocklin, V. Pirrone et al., "Introducing metallocene into a triazole peptide conjugate reduces its off-rate and enhances its affinity and antiviral potency for HIV-1 gp120," Journal of Molecular Recognition, vol. 22, no. 2, pp. 169-174, 2009.
[21] A. K. Feldman, B. Colasson, and V. V. Fokin, "One-pot synthesis of 1,4-disubstituted 1,2,3-triazoles from in situ generated azides," Organic Letters, vol. 6, no. 22, pp. 3897-3899, 2004.

[22] H. S. G. Beckmann and V. Wittmann, "One-pot procedure for diazo transfer and azide-alkyne cycloaddition: triazole linkages from amines," Organic Letters, vol. 9, no. 1, pp. 1-4, 2007.

[23] S. Chittaboina, F. Xie, and Q. Wang, "One-pot synthesis of triazole-linked glycoconjugates," Tetrahedron Letters, vol. 46, no. 13, pp. 2331-2336, 2005.

[24] J. S. Yadav, B. V. S. Reddy, G. M. Reddy, and D. N. Chary, "Three component, regioselective, one-pot synthesis of $\beta$ hydroxytriazoles from epoxides via "click reactions'”' Tetrahedron Letters, vol. 48, no. 49, pp. 8773-8776, 2007.

[25] K. Izawa and T. Onishi, "Industrial syntheses of the central core molecules of HIV protease inhibitors," Chemical Reviews, vol. 106, no. 7, pp. 2811-2827, 2006.

[26] P. E. Wilcox, D. M. Segal, J. C. Powers, G. H. Cohen, and D. R. Davies, "Substrate binding site in bovine chymotrypsin $\mathrm{A}_{\gamma}$. Crystallographic study using peptide chloromethyl ketones as site-specific inhibitors," Biochemistry, vol. 10, no. 20, pp. 37283738, 1971.

[27] J. C. Powers and P. M. Tuhy, "Active-site specific inhibitors of elastase," Biochemistry, vol. 12, no. 23, pp. 4767-4774, 1973.

[28] E. M. Gordon, J. D. Godfrey, J. Pluscec, D. von Langen, and S. Natarajan, "Design of peptide derived amino alcohols as transition-state analog inhibitors of angiotensin converting enzyme," Biochemical and Biophysical Research Communications, vol. 126, no. 1, pp. 419-426, 1985.

[29] J. R. Luly, J. J. Plattner, H. Stein et al., "Modified peptides which display potent and specific inhibition of human renin," Biochemical and Biophysical Research Communications, vol. 143, no. 1, pp. 44-51, 1987.

[30] S. Thaisrivongs, "Chapter 14. HIV protease inhibitors," Annual Reports in Medicinal Chemistry, vol. 29, no. C, pp. 133-144, 1994.

[31] J. C. Powers and P. E. Wilcox, "Design and synthesis of inhibitors for crystallographic studies on the active site of chymotrypsin," Journal of the American Chemical Society, vol. 92, no. 6, pp. $1782-1783,1970$.

[32] J. M. Concellón, P. L. Bernad, E. Riego, S. García-Granda, and A. Forcén-Acebal, "The first synthesis of enantiopure $\alpha$ amino ketimines and amino aziridines," The Journal of Organic Chemistry, vol. 66, no. 8, pp. 2764-2768, 2001.

[33] J. Barluenga, B. Baragaña, and J. M. Concellón, "Preparation and synthetic applications of enantiopure (2S,3S)- or (2R,3S)2-halomethyl-1,2-epoxyalkan-3-amines," Journal of Organic Chemistry, vol. 64, no. 8, pp. 2843-2846, 1999.

[34] J. Barluenga, B. Baragana, J. M. Concellón, A. Piñera-Nicolás, M. Rosario Díaz, and S. García-Granda, "Synthesis of enantiopure $\alpha$-amino $\alpha$, $\beta$-epoxy ketones from $\alpha$ '-amino bromomethyl ketones," The Journal of Organic Chemistry, vol. 64, no. 14, pp. 5048-5052, 1999.

[35] J. Barluenga, B. Baragaña, and J. M. Concellón, "Synthetic applications of 1-aminoalkyl chloromethyl ketones. Synthesis of enantiopure 3-azetidinols and aminoalkyl epoxides," The Journal of Organic Chemistry, vol. 62, no. 17, pp. 5974-5977, 1997.

[36] J. Barluenga, B. Baragaña, and J. M. Concellón, "Highly diastereoselective synthesis of threo or erythro aminoalkyl epoxides from $\alpha$-amino acids," The Journal of Organic Chemistry, vol. 60, no. 21, pp. 6696-6699, 1995.

[37] J. Barluenga, B. Baragaña, A. Alonso, and J. M. Concellón, “The first direct preparation of chiral functionalised ketones and 
their synthetic uses," Journal of the Chemical Society, Chemical Communications, no. 8, pp. 969-970, 1994.

[38] R. Saini, K. Dangwal, H. Singh et al., "Antioxidant and antiproliferative activities of phenolics isolated from fruits of Himalayan yellow raspberry (Rubus ellipticus)," Journal of Food Science and Technology, vol. 1-7, 2012.

[39] G. Sudha, S. Vadivukkarasi, R. B. I. Shree, and P. Lakshmanan, "Antioxidant activity of various extracts from an edible mushroom pleurotus eous," Food Science and Biotechnology, vol. 21, no. 3, pp. 661-668, 2012.

[40] S. P. Griffin and R. Bhagooli, "Measuring antioxidant potential in corals using the FRAP assay," Journal of Experimental Marine Biology and Ecology, vol. 302, no. 2, pp. 201-211, 2004.

[41] S. Gurudeeban, T. Ramanathan, and K. Satyavani, "Antimicrobial and radical scavenging effects of alkaloid extracts from Rhizophora mucronata," Pharmaceutical Chemistry Journal, vol. 47, no. 1, pp. 50-53, 2013.

[42] J. L. Guil-Guerrero, C. Martínez-Guirado, M. Del Mar Rebolloso-Fuentes, and A. Carrique-Pérez, "Nutrient composition and antioxidant activity of 10 pepper (Capsicum annuun) varieties," European Food Research and Technology, vol. 224, no. 1, pp. 1-9, 2006.

[43] A. Ochoa-Terán, J. M. Concellón, and I. A. Rivero, "Synthesis of enantiopure trisubstituted piperidines from a chiral epoxyaziridine and $\alpha$-amino esters," Arkivoc, vol. 2009, no. 2, pp. 288-297, 2009.

[44] A. Ochoa-Terán and I. A. Rivero, "Synthesis of enantiopure 1,3oxazolidin-2-ones from $\alpha$-dibenzylamino esters," Arkivoc, vol. 2008, no. 14, pp. 340-343, 2008.

[45] J. M. Concellón, E. Riego, I. A. Rivero, and A. Ochoa, "Synthesis of chiral amino epoxyaziridines: useful intermediates for the preparation of chiral trisubstituted piperidines," The Journal of Organic Chemistry, vol. 69, no. 19, pp. 6244-6248, 2004.

[46] J. I. Sarmiento-Sánchez, A. Ochoa-Terán, and I. A. Rivero, "Conventional and microwave assisted synthesis of 1,4disubstituted 1,2,3-triazoles from Huisgen cycloaddition," Arkivoc, vol. 2011, no. 9, pp. 177-188, 2011.

[47] J. I. Sarmiento-Sánchez, G. Aguirre, and I. A. Rivero, "1-Benzyl4-(naphthalen-1-yl)-1H-1,2,3-triazole," Acta Crystallographica Section E: Structure Reports Online, vol. 67, no. 7, Article ID o1856, 2011.

[48] D. E. Mendes and A. M. Schoffstall, "Citrus peel additives for one-pot triazole formation by decarboxylation, nucleophilic substitution, and azide-alkyne cycloaddition reactions," Journal of Chemical Education, vol. 88, no. 11, pp. 1582-1585, 2011.

[49] D. Kumar, G. Patel, and V. B. Reddy, "Greener and expeditious synthesis of 1,4-disubstituted 1,2,3-triazoles from terminal acetylenes and in situ generated $\alpha$-azido ketones," Synlett, vol. 2009, no. 3, pp. 399-402, 2009.

[50] K. Mishra, H. Ojha, and N. K. Chaudhury, "Estimation of antiradical properties of antioxidants using DPPH- assay: a critical review and results," Food Chemistry, vol. 130, no. 4, pp. 1036-1043, 2012.

[51] P. M. Sivakumar, P. K. Prabhakar, and M. Doble, "Synthesis, antioxidant evaluation, and quantitative structure-activity relationship studies of chalcones," Medicinal Chemistry Research, vol. 20, no. 4, pp. 482-492, 2011. 

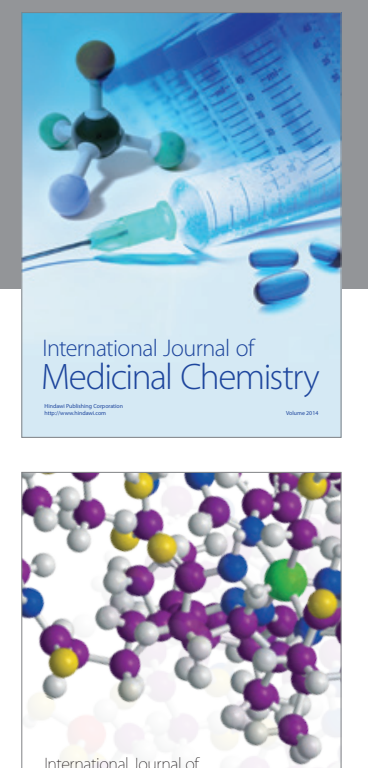

\section{Carbohydrate} Chemistry

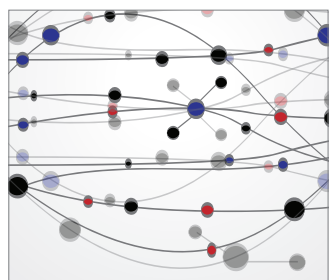

The Scientific World Journal
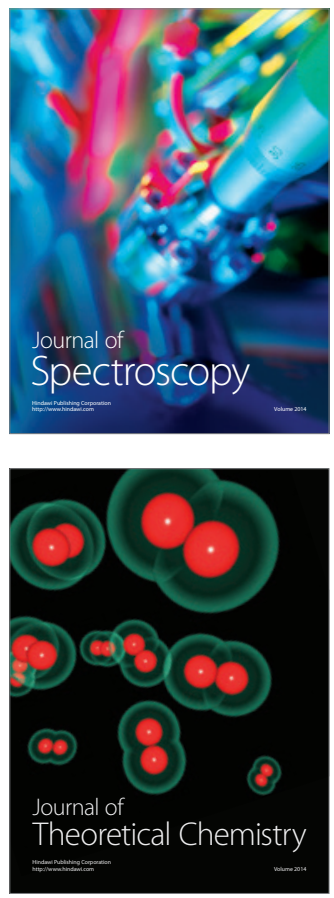
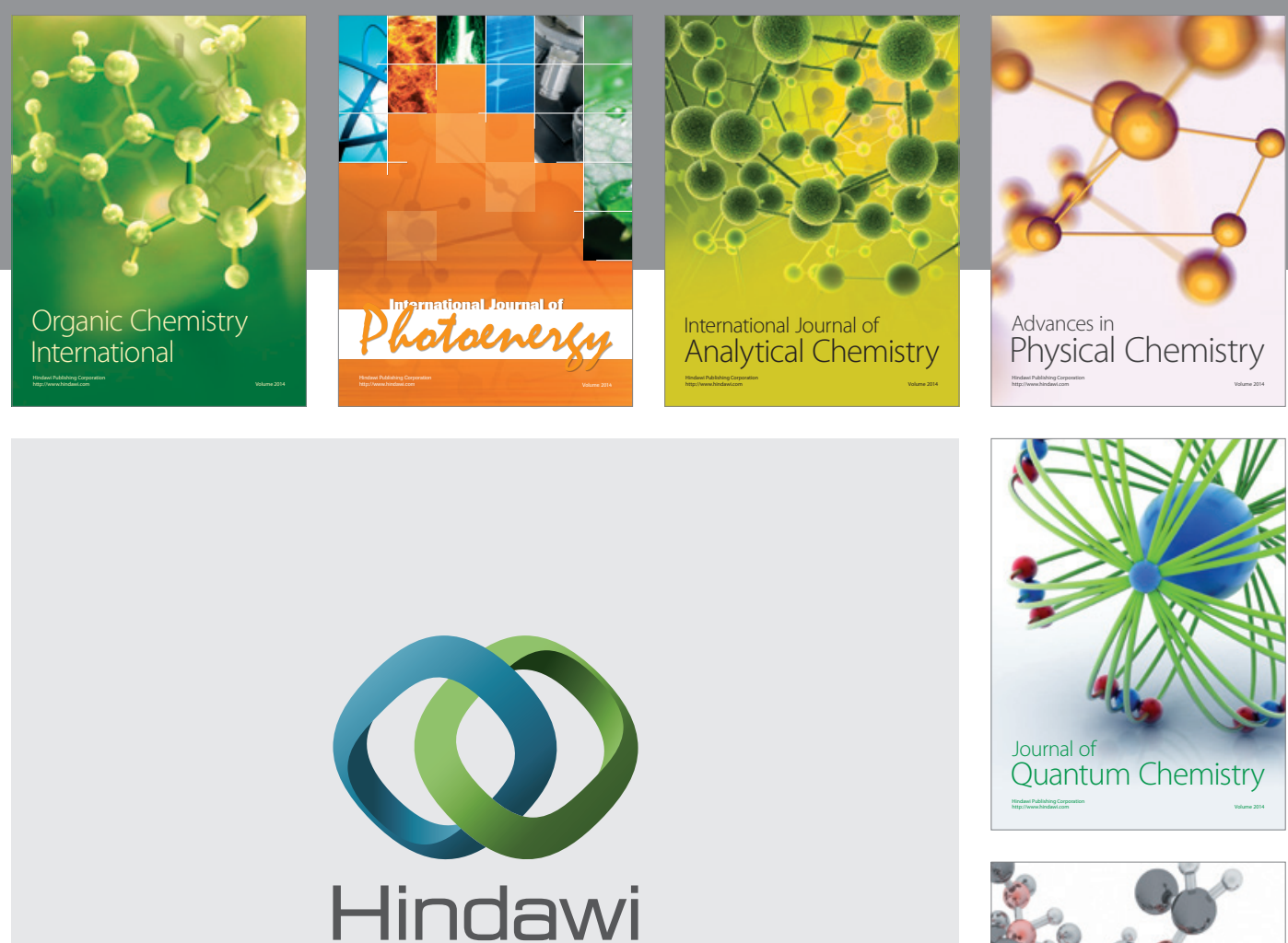

Submit your manuscripts at

http://www.hindawi.com

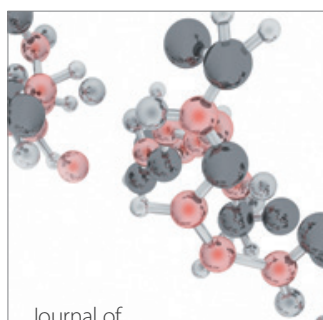

Analytical Methods

in Chemistry

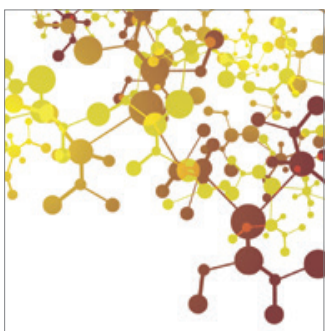

Journal of

Applied Chemistry

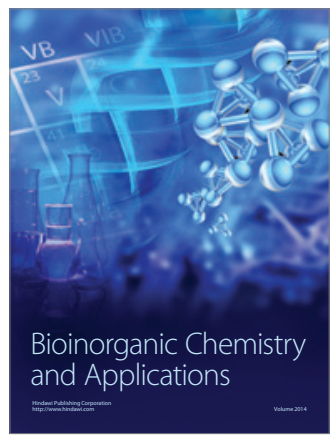

Inorganic Chemistry
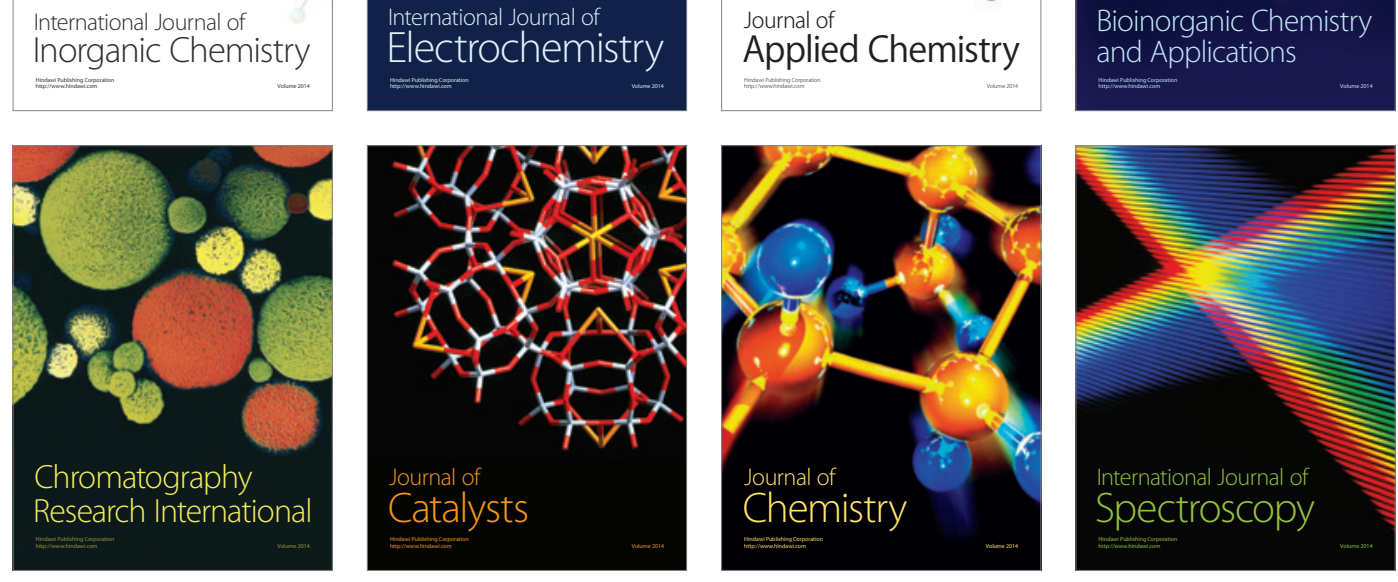